УДК 658.5.011 : 005.915

Савицька О. М.

канд. економ. наук, доцент

Скляр А. Ю.

Національний технічний університет Украӥні «КПІ»

\title{
ПЕРЕДУМОВИ ФОРМУВАННЯ КОНЦЕПЦІЇ АНТИКРИЗОВОГО ФІНАНСОВОГО КОНТРОЛІНГУ НА ПІДПРИЕМСТВІ В КОНТЕКСТІ РОЗВИТКУ ІНФОРМАЦІЙНОЇ ЕКОНОМІКИ
}

\author{
ПРЕДПОСЫЛКИ ФОРМИРОВАНИЯ КОНЦЕПЦИИ АНТИКРИЗИСНОГО \\ ФИНАНСОВОГО КОНТРОЛЛИНГА НА ПРЕДПРИЯТИИ В КОНТЕКСТЕ \\ РАЗВИТИЯ ИНФОРМАЦИОННОЙ ЭКОНОМИКИ
}

\section{BACKGROUND OF FORMING OF CONCEPT OF ANTI-CRISIS FINANCIAL CONTROLLING AT THE ENTERPRISE IN THE CONTEXT OF DEVELOPMENT OF THE INFORMATION ECONOMY}

\begin{abstract}
Визначено актуальність формування концепиії антикризового фінансового контролінгу на підприємстві в контексті розвитку інформаційної економіки, яка передбачає необхідність формування візії компанії в умовах трансформачійних змін в системі ї управління, формує програму впровадження інформаційно-комунікаційних технологій та інтеграції інформаційних потоків на підприємстві з метою оперативного реагування на фактори зовнішнього та внутрішнього середовища організації; представлено результати аналізу основних показників фінансової стійкості та платоспроможності досліджуваного підприємства; виявлено передумови впровадження конщепчії антикризового фінансового контролінгу на підприємстві; доведено, щзо запровадження трансформаційних змін в систему антикризового управління на основі системного підходу та інтеграції організаційно-економічного й інформаційного забезпечення в контексті розвитку контролінгу на підприємстві надає змогу оперативно контролювати процес виконання поставлених цілей та допомагає підвищити ефективність його функиіонування в умовах економічної та політичної нестабільності в країні і світі.
\end{abstract}

Ключові слова: фінансовий контролінг, концепція антикризового фінансового контролінгу.

Определена актуальность формирования конщепщии антикризисного финансового контроллинга на предприятии в контексте развития информационной экономики, которая предусматривает необходимость формирования визии компании в условиях трансформационных изменений в системе её управления, формирует программу внедрения информационно-коммуникационных технологий и интеграџии информационных потоков на предприятии с иелью оперативного реагирования на факторы внешней и внутренней среды организачии; представлено результаты анализа основных показателей финансовой устойчивости и платежеспособности исследуемого предприятия; выявлено предпосылки внедрения концепчии антикризисного финансового контроллинга на предприятии; доказано, что введение трансформационных изменений в систему антикризисного 
управления на основе системного подхода и интегращии организационно-экономического и информачионного обеспечения в контексте развития контроллинга на предприятии даёт возможность оперативно контролировать проиесс выполнения поставленных ичелей $и$ помогает повысить эффективность его функционирования в условиях экономической и политической нестабильности в стране и мире.

Ключевые слова: финансовый контроллинг, концепция антикризисного финансового контроллинга.

It was determined the relevance of forming of the concept of anti-crisis financial controlling at the enterprise in the context of the development of the information economy, which includes the need to create visions of the company in terms of transformational changes in the system it controls, forms the program of information and communication technologies and the integration of information streams at the enterprise for the purpose of rapid response to factors of the external and internal environment of the organization; the results of the analysis of the basic indicators of financial stability and solvency of the studied enterprise were presented; preconditions of introducing of the concept of anti-crisis financial controlling at the enterprise were identified; it is proved that introduction of transformational changes to system of crisis management on the basis of system approach and integration of organizational and economic and information support in the context of development of controlling the company will allow us to control quickly process of performance of goals and will help to increase the efficiency of its operations of economic and political instability in the country and the world.

Keywords: financial controlling, the concept of anti-recessionary financial controlling.

Вступ. В умовах розвитку інформаційної економіки, економічної та політичної нестабільності в Україні й підвищення конкуренції на міжнародному й вітчизняному ринках, особливої уваги у наукових дослідженнях вітчизняних і зарубіжних науковців приділяється актуальним питанням пошуку й впровадження в систему управління фінансовогосподарською діяльністю на підприємствах таких концепцій і заходів, які розроблені на превентивних заходах ведення бізнесу та ефективному адмініструванні [1, с. 76] на основі аналізу передумов та ознак прояву кризових явищ на підприємстві. Високий рівень конкуренції, зміна технологій, недосконалість законодавства, глобалізація економіки, розвиток науково-технічного прогресу, некерована динаміка зміни зовнішнього середовища та інші фактори змушують підприємства перетворюватися у складні системи функціонування бізнесу [2; 3; 4; 5, с. 493].

Для забезпечення ефективної/результативної діяльності зазначених систем бізнесу керівництву доцільно передбачити/визначити трансформаційні зміни в управлінні підприємством та координувати складові системи бізнесу за допомогою використання інструментарію контролінгу, у тому числі фінансового контролінгу, контролінгу витрат та інших напрямів розвитку контролінгу. При цьому варто формувати нові концепції управління й бізнесмоделювання процесів господарювання, які нададуть можливість у майбутньому підвищити ринкову вартість компанії та основні показники іï 
прибутковості, рентабельності, інші показники. Актуальним на думку авторів статті $є$ орієнтація ТОП-менеджменту компаній на одну 3 дійових концепцій сьогодення - антикризове управління на основі моделювання трансформаційних змін суб'єктів господарювання й забезпечення розвитку фінансового контролінгу на підприємстві - концепції антикризового фінансового контролінгу. Запропонована концепція передбачає необхідність формування візії компанії в умовах трансформаційних змін в системі ії управління, формує програму впровадження новітніх інформаційнокомунікаційних технологій та інтеграції інформаційних потоків на підприємстві 3 метою оперативного реагування на фактори зовнішнього та внутрішнього середовища організації, успішного ведення антикризових програм у систему управління підприємством на засадах проведення контрольних заходів у підсистемах функціонування бізнесу та загалом у механізмі всієї господарської діяльності суб'єкта підприємництва.

Деякі питання щодо формування концепції антикризового фінансового контролінгу в системі управління організацією розглядали: М. М. Аксентюк, Е. І. Альтман, I. І. Бажан, Н. О. Бабіна, Н. Д. Бабяк, В. О. Василенко, А. В. Гладілін, С. В. Грибан, І. Є. Давидович, М. І. Іванова, В. Д. Ковалєва, О. В. Коваленко, М. Х. Корецький, Г. Ю. Кюппер, О. П. Полтіна, Г. І. Просвєтов, М. С. Пушкар, О. М. Савицька, I. В. Семчук, М. В. Тупчій, O. О. Терещенко, I. І. Цигилик, С. Г. Фалько, Хілмар Й. Фолльмут, П. Хорват та інші вітчизняні й зарубіжні науковці, що надає можливість стверджувати про актуальність зазначеної проблематики дослідження.

Постановка завдання. Розкрити сутність концепції антикризового фінансового контролінгу, дослідити передумови формування організаційноекономічного забезпечення контролінгу на засадах системного підходу до розроблення концепції антикризового управління на підприємстві на основі аналізу ознак прояву кризових явищ та аналізу показників фінансового стану діяльності досліджуваного підприємства (ТОВ «Баядера Логістик»), визначити переваги впровадження концепції антикризового фінансового контролінгу на підприємстві, розробити пропозиції першочергових антикризових заходів для промислового підприємства ТОВ «Баядера Логістик» в контексті розвитку інформаційної економіки, а також впровадження й розвитку контролінгу в Україні.

Методологія. У ході дослідження було використано системний підхід та методологічний інструментарій економічного i фінансового аналізу, методології фінансового контролінгу, аналізу й синтезу наукових публікацій $[1-6,8]$.

Результати дослідження. В умовах розвитку інформаційної економіки, нестабільного розвитку зовнішнього та внутрішнього середовища суб'єкта підприємництва, керівники вітчизняних промислових підприємств і компаній 
змушені впроваджувати нові концепції управління, які орієнтують їх на ефективне й оперативне регулювання фінансово-господарської діяльності на основі визначених ознак прояву i впливу кризових явищ на систему функціонування бізнесу. Як було зазначено авторами статті [1, с. 76]: «зародження кризи на підприємстві, в першу чергу, стосується неефективного менеджменту» і «завдяки концепиії антикризового фінансового контролінгу, керівництво компанії має можливість налагодити процес успішного та ефективного управління на підприємстві не залежно від зміни умов ринкового середовища та підвищення рівня конкуренції».

Зупинимось на деяких аспектах зазначеної концепції в контексті розвитку інформаційної економіки.

Термін «концепція антикризового фінансового контролінгу» має на сьогоднішній день небагато трактувань [1 - 6; 8], що спростовує визначення місця зазначеної концепції в системі управління організацією. На думку авторів представленої статті, «зазначена концепція дозволяє суб'єктам господарювання удосконалити та підвищити результативність їх виробничогосподарської діяльності за рахунок створення й затвердження програми антикризового управління та формування сценарних прогнозів зміни фінансового стану підприємства під впливом факторів зовнішнього й внутрішнього середовища, а також при запобіганні ймовірності банкрутства компанії» [1, с. 76]. Крім того, зауважимо: антикризовий фінансовий контролінг - це інтегрована система інформаційних потоків в організації, яка забезпечує можливість проведення підрозділом контролінгу на підприємстві інформаційно-аналітичної діяльності в системі приватного бізнесу та надає можливість компанії удосконалювати систему контролінгу загалом та окремих іiі підсистем (контролінг ризиків, контролінг витрат, контролінг інвестицій, логістичний контролінг, фінансовий контролінг, контролінг персоналу тощо) й одночасно контролювати використання власного ресурсного потенціалу з метою формування превентивних дій в управлінні й забезпеченні ефективного функціонування і1ї діяльності в короткостроковому і довгостроковому періодах.

Іншими словами: «організаційно-економічне забезпечення розвитку контролінгу на підприємстві на засадах концепції антикризового управління являє собою інформаційно-аналітичну систему, яка заснована на забезпеченні системи підтримки управління суб'єктами господарювання, що гарантує підприємствам довгострокові можливості та стабільність їх розвитку, завдяки оперативному реагуванню на зміни зовнішнього та внутрішнього середовища компанії» (узагальнено авторами статті на основі [2 - 4]). Зауважимо, що важливим напрямом для ефективного управління підприємством та покращення його функціонування в умовах інформаційної економіки $\epsilon$ впровадження програми антикризового фінансового контролінгу, а саме: 
діагностування проблем, визначення ключових загроз успішності діяльності компанії, аналізування окремих факторів нестабільності ринкового середовища, розроблення заходів мінімізації загроз для компанії, оцінювання результативності діяльності компанії, контроль за впровадженими антикризовими діями тощо $[1$, с. 76$]$.

Як стверджують I. В. Семчук і М. В. Тупчій: «концепція антикризового управління повинна відображати базову інформацію про фінансовогосподарське становище підприємства, основні цільові орієнтири, ймовірні варіанти вирішення існуючих проблем та їх експертну оцінку» [2]. Н. О. Бабіна зазначає те, що: «антикризовий фінансовий контролінг - це сукупність взаємопов'язаних процесів, система інформаційної підтримки антикризових рішень, в основу яких покладено використання методів та процедур фінансової діагностики, методичного та інституційного забезпечення антикризового планування, контролю та ризик-менеджменту, а також визначення шляхів досягнення цілей, які підприємство ставить у процесі реалізації антикризового управління» [4].

На основі представлених наукових трактувань проведемо фінансову діагностику суб'єкта підприємництва на прикладі ТОВ «Баядера Логістик» (м. Київ, Україна) з метою виявлення можливості удосконалення концепції антикризового фінансового контролінгу та формування організаційноекономічного забезпечення розвитку контролінгу на засадах концепції антикризового управління. Базу апробації (підприємство ТОВ «Баядера Логістик») обрано авторами статті виходячи 3 позицій договірних відносин 3 керівництвом компанії (про проходження практики та підготовлення дипломної роботи Скляр А. Ю. під керівництвом Савицької О. М.), а також формування рекомендацій щодо удосконалення виробничо-господарської діяльності досліджуваного підприємства в умовах економічної та політичної нестабільності в країні й розроблення пропозицій оперативного контролювання процесів виконання поставлених цілей i підвищення ефективності його функціонування.

TOВ «Баядера Логістик» - одна 3 найбільших компаній України, яка існує на ринку з 1991 року, входить до складу «Баядера Холдинг», основним видом економічної діяльності $\epsilon$ оптова торгівля напоями в Україні. У складі компанії двадцять шість філій по Україні [7].

3 метою виявлення необхідності впровадження на підприємстві ТОВ «Баядера Логістик» концепції антикризового фінансового контролінгу проведено іiі фінансову діагностику та моніторинг стану виробничогосподарської й фінансової діяльності за період 2012 - 2014 рр.

У 2014 р. спостерігається позитивна динаміки зміни основних показників виробничо-господарської діяльності підприємства ТОВ «Баядера логістик» (обгрунтовано на основі даних фінансової звітності підприємства [7]), що 
свідчить про відносно ефективну політику управління й контрольовану політику витрачання фінансових ресурсів підприємством.

Результати дослідження показників фінансової стійкості підприємства за 2012 - 2014 pр. представлено на рис. 1.

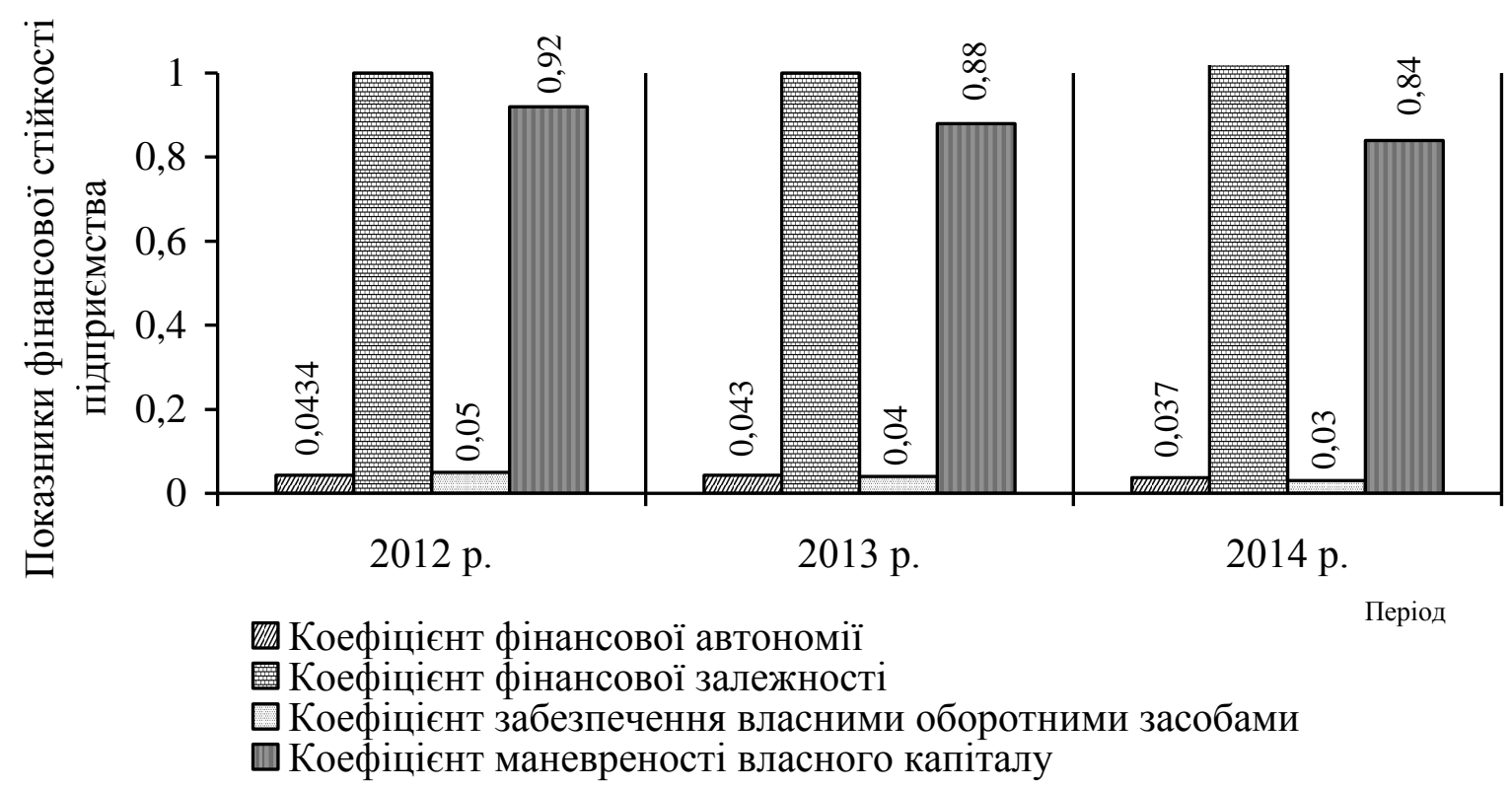

Рис. 1. Динаміка зміни основних показників фінансової стійкості ТОВ «Баядера Логістик» за 2012 - 2014 рр.

(складено авторами на основі даних звітності підприємства [7])

3 рис. 1 видно, що негативна динаміка зменшення показників фінансової стійкості за 2012 - 2014 рр. вказує на те, що підприємство є фінансово залежним від зовнішніх джерел фінансування, йому не вистачає власного капіталу для забезпечення поточної діяльності, спостерігаються певні проблеми платоспроможності (рис. 2), що $є$ характерним для більшості вітчизняних товариств 3 обмеженою відповідальністю у періоди їх економічного розвитку та посткризові періоди розвитку економіки країни.

Динаміку зміни основних показників ліквідності підприємства TOВ «Баядера Логістик» за 2012 - 2014 рр. представлено на рис. 2.

Коефіцієнт загальної ліквідності (покриття) перевищує одиницю, що означає можливість підприємства погашати поточні зобов'язання за рахунок поточних активів на $100 \%$, але він (коефіцієнт загальної ліквідності) не відповідає рекомендованим значенням достатнього рівня платоспроможності $(1,5 \div 2,0)$ і має негативу тенденцію до зниження протягом $2012-2014$ pp., що визначає недостатній рівень платоспроможності ТОВ «Баядера Логістик». Динаміка зміни коефіцієнта швидкої ліквідності має не достатньо позитивну тенденцію (незначне) зростання i формує висновок щодо незначного 
покращення стану платоспроможності досліджуваного підприємства та підтверджує можливість компанії своєчасно розраховуватися з поточними зобов'язаннями у 2013 - 2014 рр. Коефіцієнт абсолютної ліквідності не задовольняє рекомендованому значенню, але має тенденцію до зростання (від $0,01$ до 0,03$)$ і показує те, що незначну частину запозичених коштів компанія може виплатити у короткостроковий термін (лише 3 \% у 2014 р.), не очікуючи реалізації інших активів та оплати дебіторської заборгованості.

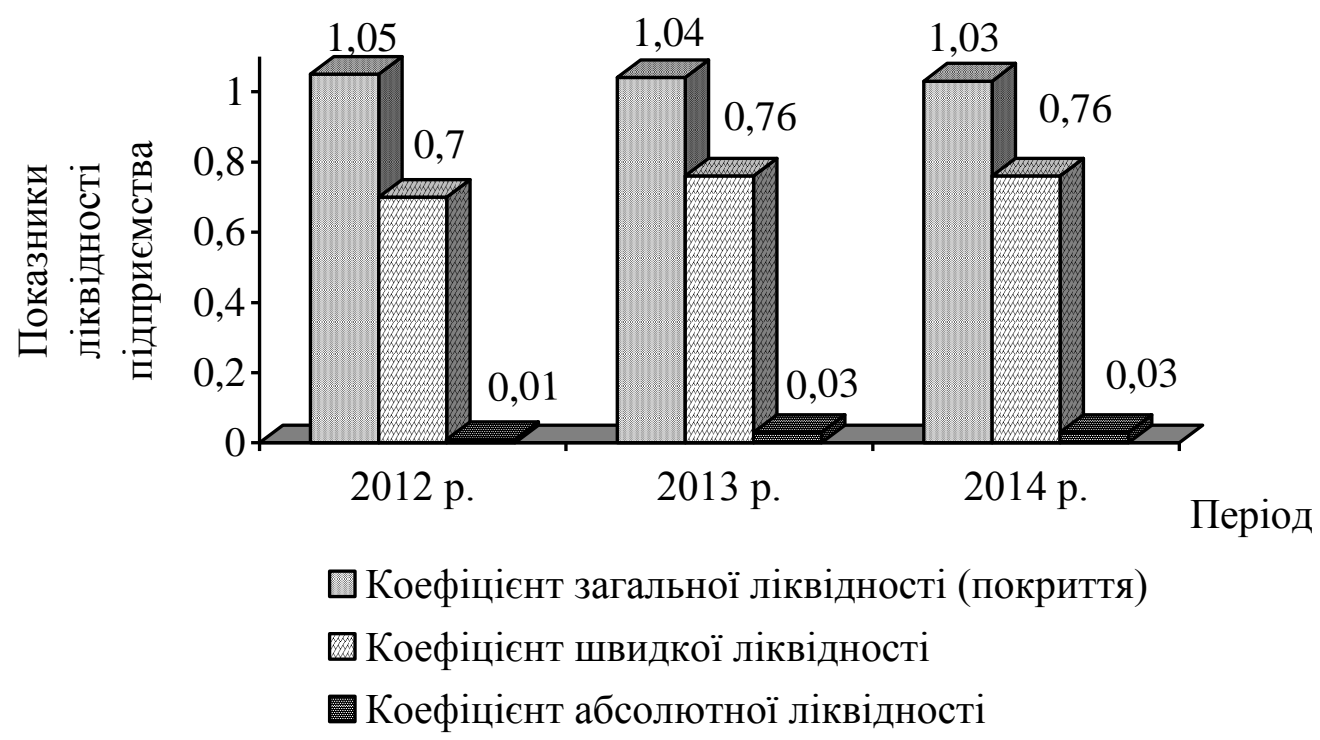

Рис. 2. Динаміка зміни основних показників ліквідності підприємства ТОВ «Баядера Логістик» за 2012 - 2014 рр.

(складено авторами на основі даних звітності підприємства [7])

Представлені результати фінансового аналізу, а також результати моніторингу й діагностики виробничої та фінансово-господарської діяльності підприємства ТОВ «Баядера Логістик» за 2012 - 2014 рр. формують бачення авторів статті стверджувати про необхідність впровадити таку концепцію антикризового управління, яка б забезпечувала економічний розвиток господарюючого суб'єкта в контексті розвитку інформаційної економіки. Підприємству ТОВ «Баядера Логістик» доцільно впровадити систему трансформаційних змін - систему антикризового фінансового контролінгу, яка мала б можливість забезпечити ефективне/результативне управління компанією та ефективне управління власним капіталом, у тому числі 3 подальшим забезпеченням підвищення фінансової стійкості організації у майбутньому та покращення показників її платоспроможності, рентабельності та інших показників за рахунок оперативної аналітичної діяльності й контролю за станом використання ресурсного потенціалу компанії за 
допомогою сучасного програмного забезпечення й інформаційнокомунікаційних технологій тощо.

Першим кроком впровадження механізму антикризового фінансового контролінгу, за результатами наукових здобутків О. В. Рибак, є «підготовча основа, яка передбачає аналіз фінансового стану та головних проблем організації. Другим є сама основа впровадження - проведення семінарів для персоналу щодо роз'яснення роботи про функціонування системи антикризового контролінгу; розроблення програми системного й комплексного підходу щодо антикризового контролінгу на основі існуючих проблем в організації для подальшого їх усунення; формування бюджету для впровадження зазначеної системи; тестування результатів щодо ефективності впровадження механізму. Останній крок, це автоматизація системи розроблення заходів оптимізації вирішення головних проблем, постійний контроль за ними та поступове вдосконалення системи на основі діагностики підприємства» [8].

На основі проведеного дослідження, визначено, що запровадження системи антикризового управління на основі організаційно-економічного забезпечення розвитку контролінгу на підприємстві ТОВ «Баядера Логістик» дозволить впроваджувати трансформаційні зміни, надасть змогу контролювати процес виконання поставлених цілей та допоможе забезпечити фінансову стійкість підприємства.

Таким чином, необхідність впровадження концепції антикризового фінансового контролінгу на підприємствах надасть можливість суб'єктам господарювання удосконалювати й підвищувати ефективність їх функціонування, запобігати проблемам в організаціях в умовах економічної та політичної нестабільності в країні і світі $[1$, с. 76$]$.

Висновки. Наукова новизна дослідження полягає в тому, що, розглянувши сутність концепції антикризового фінансового контролінгу, виявлено передумови формування організаційно-економічного забезпечення розвитку контролінгу на засадах системного підходу до розроблення концепції антикризового управління на підприємстві та на основі аналізу ознак прояву кризових явищ й діагностики показників фінансового стану діяльності досліджуваного підприємства (на прикладі ТОВ «Баядера Логістик»), визначено переваги впровадження концепції антикризового фінансового контролінгу на підприємстві в контексті розвитку інформаційної економіки та розвитку контролінгу в Україні. За результатами дослідження, авторами було представлено доцільність формування й впровадження концепції антикризового фінансового контролінгу в організації (ТОВ «Баядера Логістик»), і доведення того, що основними напрямами трансформаційних змін в контексті удосконалення системи управління 
підприємством $є$ здатність керівництва забезпечити позитивну динаміку результативного розвитку компанії.

Результати дослідження мають теоретичне та практичне значення, а саме: набули подальшого розвитку теоретичні аспекти та практичні рекомендації при формуванні концепції антикризового фінансового контролінгу на підприємстві, що на відміну від існуючих, визначають необхідність запровадження трансформаційних змін в систему антикризового управління на основі системного підходу та інтеграції організаційноекономічного й інформаційного забезпечення в контексті розвитку контролінгу на підприємстві. Зазначене надає змогу оперативно контролювати процес виконання поставлених цілей та допомагає підвищити ефективність його функціонування в умовах економічної та політичної нестабільності в країні і світі.

Подальші наукові дослідження можуть бути спрямовані на вивчення інтеграції теоретико-методологічного інструментарію контролінгу й антикризового управління на підприємстві в умовах розвитку інформаційної економіки та розвитку системи контролінгу суб'єктів господарювання.

\section{Література:}

1. Савицька О. М., Скляр А. Ю. Антикризовий фінансовий контролінг - концепція ефективного управління підприємством в умовах економічної нестабільності та підвищення конкуренції / О.М.Савицька, А. Ю. Скляр / Матеріали XIV Міжнародної наук.-практ. конференції «Розвиток підприємництва як фактор росту національної економіки», м. Київ, 25 листопада 2015 року. - К. : ІВЦ Видавництво «Політехніка», 2015. - С. 76.

2. Семчук I. В. Контролінг в системі антикризового управління підприємством [Електронний ресурс] / I. В. Семчук, М. В. Тупчій. - Режим доступу: http://nauka.kushnir.mk.ua/?p=67327.

3. Бабіна Н. О. Антикризовий фінансовий контролінг як фактор забезпечення економічної безпеки підприємства [Електронний ресурс] / Н. О. Бабіна // «Ефективна економіка», №5, 2014. - Режим доступу: http://www.economy.nayka.com.ua/?op=1\&z=3018.

4. Савицька О. М., Скляр А. Ю. Організаційно-економічні особливості антикризового управління на промислових підприємствах / О. М. Савицька, А. Ю. Скляр // Сучасні підходи до управління підприємством : Збірник наукових праць VI Всеукраїнської наук.-практич. конф. 3 міжнародною участю, 23 квітня 2015 р. - Черкаси : видавець Чабаненко Ю. А., 2015. - С. 493 - 498.

5. Сопко В. В. Контролінг як засіб забезпечення системи економічної безпеки підприємства [Електронний ресурс] / В. В. Сопко, О. М. Ромашко. - Режим доступу: http://nbuv.gov.ua/j-pdf/ape_2012_2_21.pdf.

6. Грибан С. В. Система антикризового управління підприємством [Електронний pecypc] / С. В. Грибан. - Режим доступу: http://www.economy.nayka.com.ua/?op=1\&z=2467.

7. Баядера - Імпорт [Електронний ресурс]. - Режим доступу: http://bayaderaimport.com/ru/o-kompanii. 
8. Рибак О. В. Формування механізму контролінгу в управлінні результативною діяльністю підприємства: автореф. дис. ... канд. екон. наук : 08.00.04 [Електронний pecypc] / Рибак Ольга Вікторівна ; Хмельниц. нац. ун-т. - Хмельницький, 2015. 20 c. - Режим доступу: http://www.khnu.km.ua/root/res/2-21-3-10.pdf. 